\section{Making the desert bloom}

SIR - Your witty discussion ${ }^{1}$ of the study by Nishimori and Ouchi ${ }^{2}$ of the dynamics of wind-blown sand particles treats the subject as of purely intellectual interest with some application as a diversion from boredom during seaside holidays. In fact there may be practical applications important for humanity.

I was an agricultural and building maintenance worker at Atzmona in the Northern Sinai until Israel relinquished the area to Egypt in 1982. The sand, which constantly came from the north (from the direction of the sea) would build up on the north side of any building and of most plants, eventually burying them unless we shovelled it away, a highly labourintensive occupation.

Sandy desert areas are both a resource for resettling the world's homeless and, as we Israelis have proved, places of tremendous agricultural potential. The heat and the year-round sunshine, together with the quick growth of root systems in the soft sand, give us some of the shortest times from seed to harvest in the Northern Hemisphere, especially because we grow under transparent plastic and use drip irrigation. Musk melons from Atzmona, for example, were always the first in the European markets in the spring. And every season of the year was good for some crop.

The sands, however, were always a problem. We tried to protect fields with plastic or jute screening but the sand quickly built up on the north side of the screens until it topped and covered them.

Soil that we enriched organically by ploughing in harvest waste and root systems at the end of each growing season was also quickly covered by the sands.

Research such as that by Nishimori and Ouchi may eventually find solutions to these problems, making the sandy deserts at least partial solutions to much of the world's hunger and overcrowding. Among the questions such research might answer are the following:

(1) How might one design more efficient barriers, or devices to deflect moving sand around buildings, roads and fields?

(2) Although the dunes cover most domesticated plants, date palms and some wild trees and grasses seem to remain uncovered, and the Bedouin are even able to pasture small flocks. What is it about these plants that deflects sand particles? (3) Where does the sand come from? Informal observation suggests that, in the Northern Sinai at least, it moves mostly southward, so one may hypothesize that

Letters submitted for Correspondence should be typed, double-spaced, on one side of the paper only.

\section{A. Taranta}

much of it comes from the sea. What are the dynamics of this cargo-transfer and how would such knowledge make it possible to devise a method to return the sand to the sea or to keep it there?

(4) If human control of wind-blown sand were significantly to alter major geological processes, would the long-term ecological consequences all be salutary?

\section{Frank J. Leavitt}

The Lord Immanuel Jakobovits Center

for Jewish Medical Ethics,

Ben Gurion University of the Negev,

Beer-Sheva,

Israel

1. Nature 364, 385 (1993)

2. Phys. Rev. Lett. 71, 197 (1993)

\section{Aspirin on trial}

SIR - Further to your News item about the use of aspirin in trials as a treatment for HIV (Nature 364, 369; 1993), we have recently reported at a meeting that sulfasalazine, a salycylate compound like aspirin, increased T4 cells in three AIDS patients ( $J$. Rheumat., in the press). The manuscript, now including four patients, has been submitted for publication.

These observations are preliminary, but were made in humans and may be more relevant than the in vitro preliminary observations quoted in your article.

\section{E. Disla}

H. R. Rhim

A. Reddy

Cabrini Medical Center,

227 East 19th Street,

New York, New York 10003, USA

\section{UNESCO and copyright}

SIR - Contrary to your assertion (Nature 363, 382; 1993), UNESCO has been actively concerned with the question of copyright in electronic texts.

The question was first studied within the framework of the joint action between UNESCO and the World Intellectual Property Organisation (WIPO), another UN agency, to find a solution to the copyright problems raised by the use of computers for access (storage and retrieval) of protected works. The studies prepared by the two organizations were first examined in 1979 by a working group of independent experts. Its conclusions were examined in the same year by the Intergovernmental Copyright Committee and the Executive Committee of the Berne Union, which recommended a further study of the problem at intergovernmental level. Following this recommendation, UNESCO and WIPO convened a Committee of Governmental Experts in 1980 and then a second one in 1982. The latter committee adopted a set of Recommendations to Member States on how to settle the problem.

Since then, there have been rapid developments in technology and telecommunications so that, potentially, information can be digitized, copied, stored, manipulated and delivered electronically anywhere in the world. This has raised new copyright problems for the copyright owners and their representatives as well as for librarians and their users. UNESCO is aware of all these problems and has been working closely with WIPO to establish some guiding principles. Many problems still remain that will be solved only by international organizations working in harmony.

This, I believe, is one further reason why the UK government should rejoin UNESCO; much better to be inside participating than outside jeering.

\section{Ross Shimmon}

Library Association,

7 Ridgmount Street,

London WC1E 7AE, UK

\section{Russian industry}

SIR - In your leading article "Is there a future for Russian science?" (Nature 365, 475 ; 1993) you make no mention of the need for links between science and industry. In my discussions in Moscow with senior biotechnologists and administrators in June this year, I was impressed by the lack of interest in the application of their science to a rejuvenation of their drug industry. This was particularly poignant since Realising our Potential had just been published as a White Paper (policy document) by the British government.

In terms of application, Russian scientists concentrate their efforts on the development of sophisticated drugs and vaccines which they aim to sell for hard currency. When I suggest that they should devote their efforts to their own industry they tell me that it is hopeless in the absence of large amounts of capital for new plant. But I ask myself what life would be like for our research scientists in the life sciences if we had virtually no drug industry. While I agree that it is important to try and ensure that basic science survives in Russia, more effort should be devoted to channelling scientists towards a rejuvenation of their drug industry and health services.

\section{Peter N. Campbell}

Department of Biochemistry

and Molecular Biology,

University College London,

London WC1E 6BT, UK 